\title{
MENINGKATKAN KEMAMPUAN KOMUNIKASI DAN MOTIVASI BELAJAR MATEMATIS SISWA SMP DENGAN MENGGUNAKAN PENDEKATAN RECIPROCAL TEACHING
}

\author{
Asri Adi Putri ${ }^{1)}$, Wulan Rindawanti ${ }^{2)}$, Masta Hutajulu ${ }^{3)}$, Heris Hendriana ${ }^{4)}$ \\ ${ }^{1) 2) 3) 4)}$ IKIP Siliwangi, Bandung, \\ asriadiputri3@gmail.com ${ }^{1)}$
}

\begin{abstract}
Abstrak
Penelitian ini bertujuan untuk meningkatkan kemampuan komunikasi dan motivasi belajar matematis siswa SMP dengan menggunakan pendekatan reciprocal teaching. Kurangnya kemampuan komunikasi dan motivasi belajar matematis di dalam kelas mempengaruhi hasil belajar siswa dikarenakan penggunaan metode mengajar yang tidak sesuai atau kurang tepat, untuk mengatasi hal tersebut peneliti mengambil pendekatan reciprocal teaching yang diharapkan memiliki peluang untuk mengatasi hal tersebut, dan diupayakan dapat membuat siswa aktif serta berkomunikatif dalam proses belajar-mengajar pada mata pelajaran matematika, dan kemampuan komunikasi matematis serta motivasi belajar matematika siswa akan dapat terlatih dengan baik. Penelitian ini merupakan penelitian eksperimen dengan instrumen penelitian yang digunakan adalah tes kemampuan komunikasi matematis siswa dan skala motivasi belajar matematis siswa. Penelitian ini dilakukan pada siswa kelas VII di SMP Negeri 8 Cimahi tahun pelajaran 2017/2018 semester genap. Berdasarkan hasil analisis data penelitian, diambil kesimpulan bahwa pencapaian dan peningkatan kemampuan komunikasi matematis siswa yang memperoleh pembelajaran dengan pendekatan reciprocal teaching lebih baik dibandingkan dengan siswa yang memperoleh pembelajaran biasa, dan Motivasi Belajar Matematis siswa yang pembelajarannya menggunakan pendekatan reciprocal teaching lebih baik daripada siswa yang menggunakan pembelajaran biasa.

Kata Kunci : Kemampuan Komunikasi Matematis, Motivasi Belajar, Pendekatan Reciprocal Teaching.
\end{abstract}

This study aims to improve mathematical communication ability and motivation to learn junior high school students using reciprocal teaching approach. Lack of communication ability and motivation to learn math in the classroom affect student learning outcomes due to the use of teaching methods that are not appropriate or not appropriate, in order to overcome this, the researchers took the approach reciprocal teaching which is expected to have an opportunity to overcome it, and intended to make students active and communicative in the process of teaching and learning in mathematics and mathematical communication ability and motivation to learn math students will be trained. This research is experimental research and the instrument used was a test of mathematical communication ability students and students mathematical learning motivation scale. The research was conducted on students of class VII SMP Negeri 8 Cimahi second semester of the school year 2017/2018. Based on the analysis of research data, be concluded that the achievement and improvement of mathematical communication ability students who obtain teaching approach reciprocal teaching better than students who acquire 
regular learning, and motivation mathematical student learning was using the approach reciprocal teaching better than students who use regular learning.

Keywords: Mathematical Communication Ability, Motivation Student Learning, Reciprocal Teaching Approach.

\section{PENDAHULUAN}

Pelajaran matematika mempunyai peranan yang sangat penting di dalam pendidikan, dan pendidikan merupakan salah satu komponen yang sangat penting di era globalisasi (Hutajulu, 2017). Matematika juga berfungsi untuk melayani ilmu pengetahuan artinya selain tumbuh dan berkembang untuk dirinya sendiri sebagai suatu ilmu, matematika juga melayani kebutuhan ilmu pengetahuan dalam pengembangan dan operasionalnya (Suherman, 2003). Hal tersebut memberi arti bahwa matematika merupakan ilmu dasar, baik aspek terapannya maupun aspek penalarannya dalam upaya penguasaan ilmu pengetahuan. Selain itu, matematika juga diajarkan secara formal mulai dari tingkat sekolah dasar sampai perguruan tinggi yang berarti hal tersebut merupakan indikator bahwa matematika itu sangat penting (Hutajulu \& Minarti, 2017).

Namun pada kenyataannya banyak siswa di setiap jenjang pendidikan menganggap matematika sebagai pelajaran yang sulit dan sering menimbulkan berbagai masalah yang sulit untuk dipecahkan, sehingga berdampak pada rendahnya hasil belajar, seperti pendapat yang dikemukakan Hendriana (2012) yaitu sering kita dengar tentang matematika adalah menakutkan, membosankan, membingungkan, menyebalkan dan lain-lain, menjadikan anggapan sebagian orang bahwa matematika malah membuat siswa menjadi tidak percaya diri.

Kemudian Natuonal Council of Teacher Mathematics (NCTM)
(Zannati, 2017) menetapkan bahwa terdapat lima kemampuan yang harus dimiliki siswa melalui pembelajaran matematika, yaitu 1) pemecahan masalah (problem solving); 2) penalaran dan pembuktian (reasoning and proofing); 3) komunikasi (communication); 4) koneksi (connection); dan 5) representasi (representation).

Dari uraian tersebut, kemampuan komunikasi termasuk salah satu komponen penting dalam upaya mengembangkan pembelajaran matematika. Kemampuan komunikasi harus dimiliki siswa karena komunikasi merupakan salah satu kompetensi dasar matematis disamping pemecahan masalah, penalaran dan pembuktian, koneksi, dan representasi. Peran penting komunikasi matematis juga dipaparkan oleh Hendriana, Sumarmo, \& Rohaeti (2013) bahwa komunikasi matematis merupakan representasi kemampuan pemahaman siswa terhadap konsep matematik, masalah sehari-hari, dan penerapan konsep matematika dalam disiplin ilmu lain.

Dalam kegiatan belajar mengajar, komunikasi antar pribadi merupakan peristiwa yang seharusnya muncul setiap saat antara guru dengan siswa maupun antara siswa dengan siswa. Komunikasi matematis juga merupakan salah satu komponen pembelajaran yang mempengaruhi hasil belajar siswa. Namun kemampuan komunikasi matematis di Sekolah Menengah Pertama (SMP) masih tergolong rendah, disebabkan guru masih cenderung aktif. Dalam proses belajar mengajar, guru berperan dominan dan informasi hanya berjalan satu arah dari guru ke siswa, sehingga siswa pasif. 
Sedangkan peserta didik masih cenderung terlalu pasif menerima materi dari guru, sehingga pembelajaran masih bersifat satu arah dalam proses komunikasi matematis. Hal ini mengakibatkan siswa kurang aktif dalam mengkomunikasikan pemikirannya.

Selain kemampuan komunikasi matematis, terdapat aspek psikologi atau kemampuan afektif yang turut memberikan kontribusi terhadap keberhasilan keberhasilan belajar yaitu motivasi, sebagaimana yang dikemukakan oleh Sardiman (1986) hasil belajar akan optimal kalau ada motivasi dan motivasi dapat berfungsi sebagai pendorong usaha dan pencapaian prestasi. Dalam kegiatan belajar, maka motivasi dapat dikatakan sebagai keseluruhan daya penggerak dalam diri siswa yang menimbulkan kegiatan belajar, yang menjamin kelangsungan dari kegiatan belajar, sehingga yang dikehendaki oleh subyek belajar itu dapat di tercapai.

Peran penting motivasi belajar juga dikemukakan oleh Hendriana, Rohaeti, Sumarmo (2017) dimana motivasi belajar merupakan kunci dan unsur penting dalam belajar baik bagi siswa maupun guru. Begitu juga dalam belajar matematika menurut Hudojo (1988), apabila seorang peserta didik mempunyai motivasi belajar matematika, ia akan belajar dengan sungguh-sungguh sehingga ia mempunyai pengertian yang lebih dalam. Ia dengan mudah dapat mencapai tujuan. Ini menunjukan keberhasilan itu dapat meningkatkan motivasi belajar matematika. Sebaliknya, suatu kegagalan dapat menghasilkan harga diri turun, yang berarti motivasinya turun.

Berkaitan dengan pentingnya pendidikan matematika di era globalisasi, dan pentingnya kemampuan komunikasi matematis dan motivasi belajar siswa yang mempengaruhi hasil belajar siswa sesuai dengan pemaparan di atas, adapun faktor lain yang bisa mempengaruhi hasil belajar, dan juga secara otomatis dapat mempengaruhi kemampuan komunikasi matematis dan motivasi belajar siswa. Salah satu faktornya yaitu metode pembelajaran yang digunakan. Menurut Uno (2007) metode pembelajaran diartikan sebagai cara-cara yang digunakan pengajar atau instruktur untuk menyajikan informasi atau pengalaman baru, menggali pengalaman peserta belajar, menampilkan untuk kerja peserta belajar, dan lain-lain. Metode pembelajaran dalam menjalankan fungsinya merupakan alat untuk mencapai tujuan pembelajaran.

Selanjutnya, keberhasilan belajar dapat dipengaruhi oleh guru sendiri, dimana guru masih menerapkan sistem yang menuntut guru sendiri yang aktif dibandingkan dengan siswa. Sebagaimana yang diungkapkan pleh John Locke dan Herbert (Sardiman, 1986), dalam proses belajar mengajar guru akan senantiasa mendominasi kegiatan. Siswa selalu pasif, sedangkan guru aktif dan segala inisiatif datang dari guru.

Untuk mengatasi hal tersebut perlu dicari suatu pendekatan pembelajaran terhadap siswa, yang diharapkan dapat meningkatkan kemampuan komunikasi matematis dan motivasi belajar siswa. Dari hasil kegiatan penulis, pendekatan reciprocal teaching memiliki peluang untuk mengatasi hal tersebut sejalan dengan penelitian yang telah dilakukan Rachmayani (2014) yang menyimpulkan bahwa peningkatan kemampuan komunikasi matematis siswa yang memperoleh pembelajaran reciprocal teaching lebih baik daripada siswa yang memperoleh pembelajaran 
biasa.

Sementara itu menurut Trianto (2007) pembelajaran reciprocal teaching adalah pendekatan konstruktivis yang berdasarkan pada prinsip-prinsip pembuatan atau pengajuan pertanyaan, yang dalam hal ini dapat mengurangi kesulitan yang dialami siswa mengenai komunikasi matematis yang dikemukakan oleh Hendriana, Sumarmo, \& Rohaeti (2013) berkenaan tentang menyusun pertanyaan dari suatu kasus dan menyelesaikannya. Reciprocal teaching digunakan untuk membantu siswa memusatkan perhatian apa yang sedang dibaca dan membuat siswa memahmai bacaannya. Maka dari itu pendekatan reciprocal teaching diupayakan dapat membuat siswa aktif serta berkomunikatif dalam proses belajarmengajar pada mata pelajaran matematika, dan kemampuan komunikasi matematis serta motivasi belajar matematika siswa akan dapat terlatih dengan baik.

\section{LANDASAN/KAJIAN TEORI}

\section{Kemampuan Komunikasi Matematis}

Komunikasi merupakan suatu keterampilan yang sangat penting dalam kehidupan manusia dan merupakan suatu alat bagi manusia untuk berhubungan dengan orang lain di lingkungannya baik secara verbal maupun tertulis (Hendriana, Rohaeti \& Sumarmo, 2017).

Menurut Wahyudin (2008) komunikasi adalah bagian esensial dari matematika dan pendidikan matematika. Proses komunikasi juga membantu membangun makna dan gagasan-gagasan, serta menjadikan gagasan itu diketahui publik. Tanpa komunikasi yang baik, maka perkembangan matematika akan terhambat.

Kemudian pengertian komunikasi matematis menurut Asikin (2002) adalah suatu peristiwa saling hubungan/dialog yang terjadi dalam suatu lingkungan kelas, dimana terjadi pengalihan pesan. Pesan yang dialihkan berisi tentang materi matematika yang dipelajari di kelas. Pihak yang terlibat dalam peristiwa komunikasi di lingkungan kelas adalah guru dan siswa. Sedangkan cara pengalihan pesan dapat secara tertulis maupun lisan.

Adapun pengertian komunkasi matematis juga yang dikemukakan oleh Schoen, Bean dan Zibarth (Hendriana, Rohaeti \& Sumarmo, 2017) bahwa komunikasi matematis adalah kemampuan: menjelaskan algoritma dan cara unik menyelesaikan pemecahan masalah; mengkonstruksi dan menjelaskan sajian fenomena dunia nyata secara grafik, kata-kata dan kalimat, persamaan, tabel dan sajian secara fisik; memberikan dugaan tentang gambar-gambar geometri.

Komunikasi matematis juga dapat diartikan sebagai suatu keterampilan penting dalam matematika yaitu kemampuan untuk mengekspresikan ide-ide meatematika secara koheren kepada teman, guru, dan lainnya melalui bahasa lisan dan tulisan (Armiati, 2003).

Menurut Silver, Kilpatrick, dan Schlesinger komunikasi matematis bisa mendukung belajar siswa atas konsepkonsep matematis yang baru saat mereka berperan dalam suatu situasi, mengambil, menggunakan obyekobyek, memberikan laporan dan penjelasan-penjelasan lisan, menggunakan diagram, menulis, serta mengunakan simbol-simbol matematis (Wahyudin, 2012).

Selain dapat mendukung belajar siswa komunikasi matematis juga memiliki peran penting yang dikemukakan oleh Asikin (Hendriana \& 
Sumarmo, 2014) yaitu: membantu siswa menajamkan cara siswa berpikir, sebagai alat untuk menilai pemahaman siswa, membantu siswa mengorganisasi pengetahuan matematik mereka, membantu siswa membangun pengetahuan matematikanya, meningkatkan kemampuan pemecahan masalah matematik, memajukan penalarannya, membangun kemampuan diri, meningkatkan keterampilan sosialnya, serta dapat bermanfaat dalam mendirikan komunitas matematik. Peran penting komunikasi matematis lainnya menurut Hendirana, Sumarmo \& Rohaeti (2013) adalah sebagai representasi kemampuan pemahaman siswa terhadap konsep matematik, masalah sehari-hari, dan penerapan konsep matematika dalam disiplin ilmu lain.

Terkait dengan komunikasi matematis yang memiliki peran penting sesuai dengan yang telah dipaparkan, terdapat beberapa saran menurut Pugalle dan Within (Hendriana, Rohaeti \& Sumarmo, 2017) untuk mengembangkan kemampuan komunikasi matematis di antaranya adalah: melatih kebiasaan siswa untuk menjelaskan jawabannya, memberikan tanggapan jawaban dari orang lain; melatih siswa berdiskusi, menyatakan, menjelaskan, menggambarkan, mendengar, menanyakan dan bekerja sama dalam kelompok kecil.

NCTM (Hendriana, Rohaeti \& Sumarmo, 2017) merinci indikator komunikasi matematis yang meliputi:

a) Memodelkan situasi-situasi dengan menggunakan gambar, grafik dan ekspresi aljabar; b) Mengungkapkan dan mejelaskan pemikiran tentang ideide dan situasi-situasi matematis; c) Menjelaskan ide dan definisi matematis; d) Membaca, mendengarkan, menginterpretasikan, dan mengevaluasi ide-ide matematis; e)
Mendiskusikan ide-ide matematis dan membuat dugaan-dugaan dan alasanalasan yang meyakinkan; f) Menghargai nilai, notasi matematika, dan perannya dalam masalah seharihari dan pengembangan matematika dan disiplin ilmu lainnya.

Indikator komunikasi matematis lainnya diajukan oleh TIM PPPG Matematika (Zhanty, 2011) yaitu: a) Menyajikan pernyataan matematika secara lisan, tertulis, gambar, dan diagram; b) Mengajukan dugaan; c) Melakukan manipulasi matematika; d) Menarik kesimpulan, menyusun bukti, memberikan alasan atau buktiterhadap beberapa solusi; e) Menarik kesimpulan dari pernyataan; f) Memeriksa kesahihan suatu argumen; g) Menemukan pola atau sifat dari gejala matematis untuk membuat generalisasi.

Kemudian Sumarmo (Hendriana, Rohaeti \& Sumarmo, 2017) merinci indikator komunikasi matematis ke dalam beberapa kegiatan matematis, antara lain: a) Menyatakan benda-benda nyata, situasi, dan peristiwa sehai-hari ke dalam bentuk model matematika (gambar, tabel, diagram, grafik, ekspresi aljabar); b) Menjelaskan ide, dan model matematika (gambar, tabel, diagram, grafik, ekspresi aljabar) ke dalam bahasa biasa; c) Menjelaskan dan membuat pertanyaan matematika yang dipelajari; d) Mendengarkan, berdiskusi dan menulis tentang matematika; e) Membaca dengan pemahaman suatu presentasi tertulis; dan f) Membuat konjektur, menyusun argumen, merumuskan definisi dan generalisasi. Indikator butir a) sampai dengan butir c) merupakan pedoman dalam menyusun suatu tes matematika tertulis. Sedangkan semua indikator di atas digunakan untuk mengembangkan kemampuan komunikasi matematis selama dalam pembelajaran. 


\section{Motivasi Belajar Matematis}

Menurut Hudson motivasi adalah sebagai perilaku yang ditujukan untuk mencapai suatu tujuan, sedangkan menurut Hancock motivasi adalah sebagai keinginan untuk memperbaiki kekuatan, determinasi, dan perilaku dalam melaksanakan tugas, dan mencapai tujuan, dan menurut Klein, Noe, Wang dalam seting belajar, motivasi belajar merupakan komponen kunci dalam mensleksi belajar individual (Kamarruddin, et. al, 2014).

Mc. Donald (Sardiman, 2005) mengemukakan bahwa motivasi adalah perubahan energi dalam diri seseorang yang ditandai dengan munculnya "feeling" dan didahului dengan tanggapan terhadap adanya tujuan. Selanjutnya menurut Surya (2015), bahwa motivasi adalah upaya-upaya yang dilakukan seseorang untuk menimbulkan atau meningkatkan motif yang merupakan motor penggerak atau dinamika individu dalam mencapai tujuan.

Kemudian untuk pengertian motivasi belajar atau motivasi dalam kegiatan belajar itu sendiri dikemukakan oleh Hendriana, Rohaeti \& Sumarmo (2017), motivasi belajar adalah sebagai daya penggerak di dalam diri siswa yang menimbulkan kegiatan belajar dengan berbagai perasaan atau keadaan, sehingga tujuan yang dikehendaki oleh siswa dapat tercapai dengan baik.

Sardiman (2005) mengemukakan terdapat beberapa bentuk dan cara untuk menumbuhkan motivasi dalam proses pembelajaran antara lain:

a. Menilai dan memberi angka baik dalam aspek kognitif dan keterampilan afeksinya.

b. Memberi hadiah agar siswa lebih semangat dalam belajar.

c. Menciptakan suasana bersaing yang sehat yang memotivasi siswa untuk aktif selama pembelajaran.

d. Ego-Involvment yang mendorong siswa berusaha keras mencapai prestasi yang baik dan menjaga harga dirinya.

e. Memberi ulangan.

f. Menyampaikan hasil belajar siswa yang mendorong siswa lebih giat belajar.

g. Memberi pujian yang tepat untuk memupuk suasana yang menyenangkan, mempertinggi gairah belajar, dan membangkitkan harga diri.

h. Memberi hukuman secara tepat dan bijak agar tidak terjadi pengulangan hal yang tidak diinginkan.

i. Menumbuhkan hasrat untuk belajar.

j. Memperhatikan minat siswa.

k. Menjelaskan tujuan belajar yang berguna dan menguntungkan sehingga menimbulkan gairah untuk terus belajar.

Menurut Sardiman (2005) motivasi belajar berfungsi untuk mendorong manusia untuk berbuat, menentukan arah perbuatan, dan menyeleksi perbuatan mana yang akan dilakukan. Kemudian menurut Hamzah (2008) \& Uno (2008) terdapat empat peran penting motivasi dalam belajar, antara lain: a) Menentukan hal-hal yang dijadikan sebagai penguat belajar; b) Memperjelas tujuan belajar yang hendak dicapainya; c) Menentukan berbagai macam kendala terhadap rangsangan belajar; d) Menentukan ketekunan belajar siswa, agar hasil belajar menjadi maksimal. Selanjutnya fungsi motivasi belajar lainnya dikemukakan oleh Hamalik (2003) yang menjelaskan bahwa fungsi motivasi belajar ialah pengaruh yang mengarahkan perbuatan seseorang untuk mencaoai tujuan yang diinginkan dan sebagai penggerak berlangsungnya belajar siswa.

Sugihartono 
mengidentifikasi karakteristik siswa yang memiliki motivasi belajar yang tinggi, antara lain: a) Kualitas keterlibatan kognitif siswa yang sangat tinggi selama proses kegiatan belajar mengajar; b) Keterlibatan afektif siswa yang tinggi; c) Upaya siswa dalam mempertahankan motivasi belajarnya.

Kemudian Hamzah (2008) \& Uno (2008) merinci indikator motivasi belajar sebagai berikut: a) Hasrat dan keinginan untuk berhasil; b) Dorongan dan kebutuhan dalam belajar; c) Citacita dan harapan di masa depan; d) Penghargaan dalam belajar; e) Kegiatan yang menarik perhatian dalam belajar; f) Lingkungan belajar yang kondusif. Indikator motivasi belajar lainnya yang dikemukakan oleh Sardiman (2005) yaitu: a) Tekun menghadapi tugas; b) Ulet menghadapi kesulitan; c) Menunjukkan minat terhadap bermacam-macam masalah; d) Lebih senang bekerja mandiri; e) Cepat bosan pada tugas-tugas yang rutin; f) Dapat mempertahankan pendapatnya; g) Tidak mudah melepaskan hal yang diyakini; h) Senang mencari dan memecahkan masalah yang kompleks.

Berdasarkan uraian di atas secara garis besar terdapat dua kelompok indikator pendorong motivasi belajar siswa, yaitu: a) Dorongan internal yang meliputi hasrat dan keinginan berhasil, dorongan dan kebutuhan dalam belajar, harapan dan cita-cita masa depan, dan faktor fisiologis; b) Dorongan eksternal yang meliputi kegiatan yang menarik dalam belajar dan lingkungan belajar yang kondusif (Hendriana, Rohaeti \& Sumarmo, 2017).

\section{Pendekatan Reciprocal Teaching}

Menurut Palincsar dan Brown (Effendi, 2013) Reciprocal Teaching adalah pendekatan konstruktivis yang didasarkan pada prinsip-prinsip membuat pertanyaan, mengajarkan keterampilan metakognitif melalui pengajaran, dan pemodelan oleh guru untuk meningkatkan keterampilan membaca pada siswa yang berkemampuan rendah, juga melatih keterampilan metakognisi melalui empat strategi yaitu: 1) Menyusun pertanyaan-pertanyaan dari teks bacaan dan jawabannya; 2) Membuat rangkuman (ringkasan informasiinformasi penting dari teks bacaan; 3) Membuat prediksi, dan 4) Mengidentifikasi hal-hal yang kurang jelas dan memberikan klarifikasi (penjelasan). Namun Palincsar \& Brown juga menyatakan bahwa urutan keempat tahapan strategi yang terjadi dalam pembelajaran reciprocal teaching adalah tidak penting.

$$
\text { Menurut Suyatno }
$$

reciprocal teaching merupakan strategi pembelajaran berdasarkan prinsipprinsip pengajuan pertanyaan dimana siswa keterampilan-keterampilan metakognitif diajarkan melalui pengajaran langsung dan pemodelan guru. Menurut Rachmayani (2014), reciprocal teaching adalah suatu pendekatan pembelajaran yang menerapkan empat strategi pemahaman mandiri, yaitu menyimpulkan bahan ajar, menyusun pertanyaan dan menyelesaikannya, menjelaskan kembali pengetahuan yang telah diperolehnya, kemudian memprediksikan pertanyaan selanjutnya dari persoalan yang disodorkan kepada siswa.

Kemudian Abdul (2007) mengungkapkan bahwa kelebihan reciprocal teaching antara lain: a) Mengembangkan kreativitas siswa; b) Memupuk kerjasama antara siswa; c) Menumbuhkan bakat siswa terutama dalam berbicara dan mengembangkan sikap; d) Siswa lebih memperhatikan pelajaran karena menghayati sendiri; e) Memupuk keberanian berpendapat dan berbicara di depan kelas; f) Melatih 
siswa untuk menganalisa masalah dan mengambil kesimpulan dalam waktu singkat; g) Menumbuhkan sikap menghargai guru karena siswa akan merasakan perasaan guru pada saat mengadakan pembelajaran terutama pada saat siswa ramai atau kurang memperhatikan; dan h) Dapat digunakan untuk materi pelajaran yang banyak dan alokasi waktu yang terbatas.

Dari pendekatan reciprocal teaching yang telah dijelaskan, berikut contoh sederhana dari penerapan pendekatan reciprocal teaching dalam pembelajaran matematika (Hendriana \& Afrilianto, 2017):

1. Menyampaikan tujuan, memotivasi siswa dan mengadakan apersepsi.

Guru menyampaikan semua tujuan pembelajaran yang ingin dicapai pada pelajaran tersebut, memotivasi siswa agar bersungguh-sungguh dalam belajar dan menggali pengetahuan awal siswa melalui kegiatan apersepsi.

2. Menyajikan informasi (materi).

Guru menyajikan informasi

(materi) kepada siswa baik secara langsung di papan tulis, penjelasan lebih detail mengembangkan konsep yang ada dalam buku teks maupun dengan peragaan (demonstrasi) disertai contohcontoh yang jelas.

3. Menyimpulkan materi (summarizing)

Guru memberikan kesempatan kepada siswa untuk menyimpulkan materi yang sudah disampaikan.

4. Menyusun pertanyaan atau soal (question generating)

Guru memberikan tugas kepada siswa untuk menyusun soal dan menyelesaikannya sendiri sekaligus meminta beberapa siswa untuk mempresentasikan hasil kerjanya di depan kelas.
5. Menjelaskan kembali (clarifying) Guru meminta siswa menjelaskan kembali pengetahuan yang telah diperolehnya agar siswa benarbenar mampu menguasai konsep yang telah diberikan.

6. Memprediksi soal (predicting)

Guru memberi tugas kepada siswa untuk memprediksi soal yang lebih sulit dari soal-soal latihan yang telah diberikan sebelumnya.

7. Menutup pembelajaran

Guru bersama-sama siswa merangkum hasil pembahasan, melakukan refleksi dan memberikan PR.

Dilihat dari strategi yang diterapkan pada contoh penerapan pendekatan reciprocal teaching di atas dapat disimpulkan bahwa pendekatan reciprocal teaching merupakan strategi dalam pembelajaran yang menekankan pada pemahaman mandiri siswa, sehingga dapat meningkatkan penguasaan konsep matematika Hendriana \& Afrilianto (2017).

Secara keseluruhan dapat disimpulkan bahwa pendekatan reciprocal teaching adalah pembelajaran yang tercapai melalui kegiatan belajar mandiri yang menerapkan empat strategi pemahaman mandiri, yaitu : menyimpulkan bahan ajar (summarizing), menyusun pertanyaan dan menyelesaikannya (questioning), menjelaskan kembali pengetahuan yang telah diperolehnya (clarifying), dan memprediksikan pertanyaan apa selanjutnya dari persoalan yang diberikan kepada siswa (predicting).

\section{METODE PENELITIAN Jenis Penelitian}

Metode yang digunakan dalam penelitian ini adalah penelitian kuasi eksperimen. Pada kuasi eksperimen subjek tidak dikelompokkan secara 
acak, tetapi peneliti menerima keadaan subjek seadanya. Sugiyono menyatakan bahwa di dalam penelitian kuasi eksperimen ada perlakuan (treatment) yang diberikan kepada kelompokkelompok tertentu, dengan demikian metode penelitian kuasi eksperimen adalah "sebuah metode yang digunakan untuk mencari pengaruh sebuah perlakuan tertentu terhadap objek-objek yang ingin diteliti dalam kondisi yang terkendalikan" (Sugiyono, 2012). Desain penelitian yang digunakan dalam penelitian ini dapat digambarkan sebagai berikut:

$$
\begin{aligned}
& \mathrm{O} \times \mathrm{O} \\
& \text { - - - } \\
& \text { O O }
\end{aligned}
$$

Sumber: Sugiyono (2012)

\section{Keterangan:}

- - - : Pengambilan sampel

tidak secara acak kelas

$\mathrm{O} \quad$ : Pretest $=$ Posttest

$\mathrm{X}$ : Pembelajaran dengan menggunakan pendekatan reciprocal teaching

\section{Waktu dan Tempat Penelitian}

Penelitian ini dilakukan di SMP Negeri 8 Cimahi kelas VII tahun pelajaran 2017/2018 semester genap dengan materi Segiempat dan Segitiga.

\section{Subjek Penelitian}

Subjek dalam penelitian ini dikelompokkan dalam 2 kelas VII yang dipilih, yaitu kelas VII E sebagai kelas eksperimen yang pembelajarannya menggunakan pendekatan reciprocal teaching dan kelas VII B sebagai kelas kontrol yang menggunakan pembelajaran biasa.

\section{Instrumen dan Teknik Pengumpulan Data}

Instrumen dalam penelitian ini terbagi menjadi dua, yang pertama adalah seperangkat soal tes berbentuk uraian (instrumen tes) dan yang kedua adalah seperangkat tes berbentuk angket (instrumen non tes). Instrumen tes dikembangkan sendiri oleh peneliti, agar memiliki validitasi logis yang didasarkan pada hasil pemikiran (Hendriana \& Sumarmo, 2014) maka soal-soal tersebut dikonsultasikan terlebih dahulu dengan dosen pembimbing. Setelah itu agar memiliki validitas empiris yang didasarkan pada pengalaman (Hendriana \& Sumarmo, 2014) maka soal-soal tersebut diujicobakan pada kelas eksperimen dan kelas kontrol. Kemudian dihitung validitas, reliabilitas, daya pembeda dan indeks kesukarannya.

\section{Instrumen Tes}

Dalam penelitian ini, tes yang diberikan akan digunakan untuk mengetahui kemampuan komunikasi matematis siswa dan dilakukan sebanyak dua kali yaitu tes kemampuan awal (pretest) dan tes kemampuan akhir (posttest) dengan indikator kemampuan komunikasi matematis.

Sebelum soal diberikan kepada siswa, soal itu harus dianalisis validitas, reliabilitas, daya pembeda dan indeks kesukaran soal. Sebuah tes dikatakan valid apabila tes tersebut mengukur apa yang hendak diukur (Hendriana \& Sumarmo, 2014). Sehingga hal tersebut sangat penting diuji terlebih dahulu agar hasil yang didapatkan memenuhi standar penilaian.

Dari hasil analisis validitas, reliabilitas, daya oembeda dan indeks kesukaran, peneliti mengambil 5 soal dari 10 soal dengan mempertimbangkan indikator kecapaian kemampuan komunikasi matematis.

\section{Instrumen Non Tes}

Penilaian skala motivasi belajar matematis siswa dalam penelitian ini menggunakan angket. Suherman dan Sukjaya (Wirantiwi, 2011) mengemukakan bahwa angket adalah sebuah daftar pernyataan yang harus diisi oleh orang yang akan dievaluasi (responden). Tujuan pembuatan angket 
ini adalah untuk mengetahui motivasi belajar matematis siswa terhadap pembelajaran matematika, khususnya dengan menggunakan pembelajaran reciprocal teaching.

Penelitian ini menggunakan dua puluh enam butir skala motivasi belajar matematis siswa SMP dengan lima indikator yang diadaptasi dari Sahara (Hendriana Rohaeti, \& Sumarmo, 2017) yang dikembangkan oleh peneliti dan sudah divalidasi.

\section{Teknik Analisis Data}

Data dalam penelitian ini dikumpulkan melalui tes dan angket. Data yang berkaitan dengan kemampuan Komunikasi Matematis Siswa dikumpulkan melalui tes. Sementara data Motivasi Matematis Siswa dengan pendekatan Reciprocal Teaching dikumpulkan melalui angket.

Data yang akan dianalisis adalah data kuantitatif berupa hasil tes kemampuan Komunikasi Matematis Siswa, dan data kualitatif berupa angket Motivasi Belajar Matematis untuk siswa. Seluruh data hasil penelitian diolah menggunakan software SPSS 22

\section{Tabel 1}

Rekapitulasi Hasil Pretest, Posttest dan N-Gain Kemampuan Komunikasi serta Motivasi Belajar Matematis Siswa

\begin{tabular}{|c|c|c|c|c|c|c|c|}
\hline \multirow[t]{2}{*}{ Variabel } & \multirow[t]{2}{*}{ Statistik } & \multicolumn{3}{|c|}{$\begin{array}{c}\text { Kelompok Eksperimen } \\
(n=32)\end{array}$} & \multicolumn{3}{|c|}{$\begin{array}{c}\text { Kelompok Kontrol } \\
(n=32)\end{array}$} \\
\hline & & Pretest & Posttest & N-Gain & Pretest & Posttest & N-Gain \\
\hline \multirow{3}{*}{$\begin{array}{c}\text { Komunikasi } \\
\text { Matematis }\end{array}$} & $\bar{x}$ & 0,78 & 12,28 & 0,61 & 0,63 & 7,88 & 0,38 \\
\hline & $\%$ & 3,90 & 61,40 & 3,05 & 3,15 & 39,40 & 1,9 \\
\hline & $s$ & 1,91 & 3,72 & 0,18 & 0,75 & 2,78 & 0,13 \\
\hline Motivasi & $\bar{x}$ & 72,02 & 75,20 & 0,07 & 72,13 & 69,72 & $-0,12$ \\
\hline Belajar & $\%$ & 69,25 & 72,31 & 0,07 & 69,36 & 67,04 & $-0,12$ \\
\hline Matematis & $s$ & 8,87 & 7,03 & 0,18 & 8,87 & 10,68 & 0,35 \\
\hline
\end{tabular}

Catatan: Skor ideal komunikasi matematis $=20$

\section{Skor ideal motivasi belajar matematis $=104$}

Analisis Skor Pretest dan Posttest Kemampuan Komunikasi Matematis Analisis skor menggunakan uji perbedaan rataan skor pretest dan skor posttest dengan menggunakan Mann Whitney. Uji perbedaan rataan skor pretest dan posttest bertujuan untuk melihat apakah terdapat perbedaan yang signifikan terhadap kemampuan komunikasi matematis awal dan kemampuan komunikasi akhir. 
Tabel 2

Data Hasil Uji Perbedaan Rataan Skor Pretest Kemampuan Komunikasi Matematis

\begin{tabular}{lr}
\hline & Nilai Pretes \\
\hline Asymp. Sig. (2-tailed) & 0,171 \\
\hline
\end{tabular}

Dari hasil uji-t di atas didapat nilai kontrol. Kemudian dilanjutkan dengan $\operatorname{Sig}(2$-tailed) yaitu $0,171>0,05$. Hal ini uji perbedaan rataan skor posttest menunjukkan bahwa H0 diterima. dengan menggunakan uji Mann Artinya tidak terdapat perbedaan yang Whitney, untuk melihat apakah signifikan antara skor pretest kemampuan akhir kelas eksperimen kemampuan komunikasi matematis lebih baik dari kelas kontrol. siswa kelas eksperimen dengan kelas

Tabel 3

Data Hasil Uji Perbedaan Rataan Skor Posttest Kemampuan Komunikasi Matematis

\begin{tabular}{cr}
\hline Mann-Whitney $U$ & 173,500 \\
\cline { 1 - 2 } Monte Carlo Sig. (1-tailed) & 0,000
\end{tabular}

Dari hasil uji-t di atas didapat nilai Sig.(2-tailed) yaitu 0,00. Penelitian ini menggunakan hipotesis satu pihak (1tailed), dan diperoleh nilai Sig. (1tailed) 0,00. Karena nilai signifikansi $0,00<0,05$ maka Ho ditolak. Artinya pencapaian kemampuan komunikasi matematis siswa yang mendapatkan pendekatan Reciprocal Teaching lebih baik daripada siswa yang mendapatkan pembelajaran biasa.

\section{Analisis Skor Gain Ternormalisasi}

Tabel 4 Kemampuan Komunikasi Matematis
Untuk melihat peningkatan kemampuan
komunikasi matematis yang telah
dicapai oleh siswa dan kualifikasinya
digunakan skor gain ternormalisasi (N-
Gain) dengan menggunakan uji-t. Skor
gain kemampuan komunikasi
matematis siswa adalah skor yang
diperoleh dari selisih skor posttest dan
pretest baik kelompok eksperimen
maupun kelas kontrol

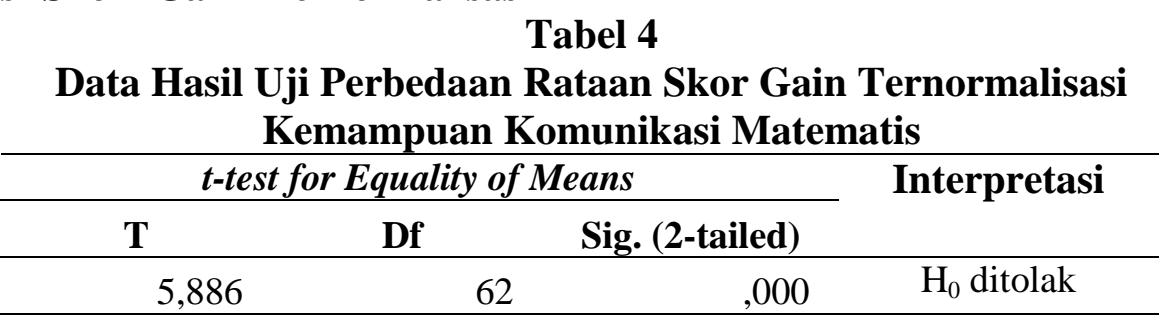

Dari hasil uji- $t$ di atas didapat

nilai Sig.(2-tailed) yaitu 0,00 . Penelitian ini menggunakan hipotesis satu pihak (1-tailed), maka nilai Sig.(2-tailed) harus dibagi menjadi 2 yaitu $0,00 / 2=0,00$. Karena nilai signifikansi $0,00<0,05$ maka Ho ditolak. Artinya pencapaian kemampuan komunikasi matematis siswa yang mendapatkan pendekatan Reciprocal Teaching lebih baik daripada siswa yang mendapatkan pembelajaran biasa. 
Hal ini sejalan dengan penelitian yang dilakukan oleh Dewi (2017) yang menyimpulkan bahwa peningkatan kemampuan komunikasi matematis siswa yang pembelajarannya menggunakan pendekatan reciprocal teaching lebih baik daripada yang pembelajarannya menggunakan pembelajaran biasa.

\section{Analisis Skala Motivasi Belajar Matematis}

Untuk melihat peningkatan motivasi belajar matematis yang telah dicapai oleh siswa dan kualifikasinya digunakan skor gain ternormalisasi $(N$-Gain) dengan menggunakan uji-t. Skor skala gain motivasi belajar matematis siswa adalah skor skala yang diperoleh dari selisih skor skala posttest dan pretest baik kelompok eksperimen maupun kelas kontrol

Tabel 5

Data Hasil Uji Perbedaan Rataan Skor Skala

Motivasi Belajar Matematis

\begin{tabular}{ccrrr}
\hline \multicolumn{4}{c}{ t-test for Equality of Means } & Interpretasi \\
\cline { 1 - 3 } T & Df & Sig. (2-tailed) & \\
\hline 2,423 & 62 & 0,018 & $\mathrm{H}_{0}$ ditolak \\
\hline
\end{tabular}

berdasarkan hasil uji-t di atas didapat nilai Sig.(2-tailed) yaitu 0,018. Penelitian ini menggunakan hipotesis satu pihak (1-tailed), maka nilai Sig.(2tailed) harus dibagi menjadi 2 yaitu $0,018 / 2=0,009$. Karena nilai signifikansi $0,009<0,05$ maka Ho ditolak. Artinya Motivasi Belajar Matematis siswa yang pembelajarannya menggunakan pendekatan Reciprocal Teaching lebih baik daripada siswa yang menggunakan pembelajaran biasa. Hal tersebut sejalan dengan penelitian yang telah dilakukan oleh Hasanah (2017) yang mana disimpulkan bahwa adanya pengaruh pendekatan pembelajaran reciprocal teaching terhadap motivasi belajar matematis siswa.

\section{KESIMPULAN DAN SARAN}

Kesimpulan

Berdasarkan hasil analisis data penelitian dan pembahasan hasil penelitian yang telah dibahas, maka diperoleh kesimpulan sebagai berikut:
1. Pencapaian
kemampuan
komunikasi matematis siswa yang

pembelajarannya menggunakan pendekatan Reciprocal Teaching lebih baik daripada siswa yang menggunakan pembelajaran biasa.

2. Peningkatan kemampuan komunikasi matematis siswa yang pembelajarannya menggunakan pendekatan Reciprocal Teaching lebih baik daripada siswa yang menggunakan pembelajaran biasa.

3. Motivasi Belajar Matematis siswa yang pembelajarannya menggunakan pendekatan Reciprocal Teaching lebih baik daripada siswa yang menggunakan pembelajaran biasa.

\section{Saran}

Berdasarkan hasil penelitian yang telah dilakukan maka peneliti mengajukan beberapa saran, yaitu:

1. Kemampuan komunikasi matematis harus sering diterapkan dalam pembelajaran sehari-hari agar siswa menjadi terbiasa dengan soal-soal kemampuan komunikasi, dan indikator yang masih terdapat kesulitan bisa dapat dicapai sehingga kemampuan komunikasi 
matematis di Indonesia semakin baik.

2. Motivasi belajar siswa selain dapat ditingkatkan melalui pendekatan reciprocal teaching, dapat ditingkatkan juga dengan pemberian reward kepada siswa yang berani tampil dan menjelaskan sesuatu di depan kelas, dan bisa juga dengan memberikan kesempatan pada siswa untuk mengungkapkan ide yang mereka miliki.

3. Menggunakan reciprocal teaching pada pembelajaran matematika dapat menjadi salah satu cara atau suatu alternatif untuk meningkatkan kemampuan komunikasi matematis dan motivasi belajar siswa.

4. Untuk penelitian lebih lanjut penerapan pendekatan reciprocal teaching di sekolah dapat dikembangkan, diantaranya meneliti kemampuan matematis lainnya yang belum terjangkau oleh penulis dan menggunakan model atau metode pembelajaran yang mendukung pada jenjang yang berbeda.

\section{DAFTAR PUSTAKA}

Abdul, A.W. (2007). Metode dan Model-Model Mengajar. Bandung: Alfabeta.

Armiati. (2003). Komunikasi Matematis dan Pembelajaran Berbasis Masalah. Disajikan dalam Semnas Matematika Universitas Katholik Parahyangan. Bandung.

Asikin, M. (2002). Daspros Pembelajaran Matematika I. (Online) Tersedia: https://www.scribd.com/documen t/13425097/Diktat-KuliahDasprosPemb-Mat1. (Diakses 15 Juni 2018).
Effendi, N. (2013). Pengaruh Pembelaaran Reciprocal

Teaching dipadukan Think Pair Share terhadap Peningkatan Kemampuan Metakognitif Belajar Biologi Siswa SMABerkemampuan Akademik Berbeda di Kabupaten Sidoarjo. Jurnal Santiaji Pendidikan. Vo; 3, No. 2.

Hamalik. (2003). Perencanaan Pengajaran Berdasarkan Pendekatan Sistem. Jakarta: PT. Bumi Aksara.

Hamzah, B. (2008). Teori Motivasi dan Pengukurannya, Analisis di Bidang Pendidikan. Jakarta: Bumi Aksara.

Hasanah, Z.N. (2017). Eksperimentasi

Model Pembelajaran Student

Teams Aschievement Division

Dengan Pendekatan Reciprocal

Teaching Pada Subpokok

Bahasan Segitiga Dan Segiempat

Ditinjau Dari Motivasi Belajar

Siswa Kelas VII SMP 2 JATEN

Tahun Pelajaran 2016/2017.

(Skripsi). Program Studi

Pendidikan Matematika,

Universitas Sebelas Maret,

Surakarta.

Hendriana, H \& Afrilianto, M. (2017).

Langkah Praktis Penelitian

Tindakan Kelas Bagi Guru.

Bandung: PT. Refika Aditama.

Hendriana, H. (2012). Pembelajaran Matematika Humanis Dengan Metaphorical Thinking Untuk Meningkatkan Kepercayaan Diri Siswa. Jurnal Infinity, 1(1), 90103.

Hendriana, H., Rohaeti, E., Sumarmo, U. (2017). Hardskills dan Softskills Matematik Siswa. Bandung: PT. Refika Aditama.

Hendriana, H \& Sumarmo, U. (2014).

Penilaian Pembelajaran

Matematika. Bandung: PT. 
Refika Aditama.

Hendriana, H., Sumarmo, U., \&

Rohaeti, E. E. (2013).

Kemampuan Komunikasi

Matematik serta Kemampuan dan

Disposisi Berpikir Kritis

Matematik. Jurnal Matematika

Dan Pendidikan Matematika, 2(1), 35-45.

Hudojo, H. (1988). Strategi Mengajar Belajar Matematika. Jakarta: Depdikbud.

Hutajulu, M. (2017). Pembelajaran Matematika Melalui Pendekatan

Keterampilan Metakognitif Dengan Model Advance Organizer untuk Meningkatkan Kemampuan Berpikir Kritis Matematik Siswa SMA, Jes-Mat. 3(1), 21-32.

Hutajulu, M., \& Minarti, E. D. (2017).

Meningkatkan Kemampuan

Advanced Mathematical

Thinking Dan Habits Of Mind

Mahasiswa Melalui Pendekatan

Keterampilan Metakognitif. JesMat, 3(2).

Kamaruddin, I., Roshidah, A. R., Mubin, M., N. \& Nurul, A. S. (2010). Pengaruh Gaya Pembelajaran terhadap Motivasi dan Pencapaian akademikPelajar pra Ijazah Sarjana Muda Perguruan Institut Pendidikan Guru Kampus Ipoh. Jurnal Penyelidikan Dedikasi, 2, 141153.

Rachmayani, D. (2014). Penerapan Pembelajaran Reciprocal Teaching untuk Meningkatkan Kemampuan Komunikasi Matematis dan Kemandirian Belajar. Jurnal Pendidikan dan Kebudayaan. Vol. 20, No.4, 441451.

Sardiman. (1986). Interaksi dan Motivasi Belajar Mengajar. Jakarta: CV. Rajawali.
Sardiman, A.M. (2005). Interaksi dan Motivasi Belajar Mengajar. Jakarta: Rajawali Press.

Sugihartono, dkk. (2007). Psikologi Pendidikan. Yogyakarta: UNY Press.

Sugiyono. (2012). Metode Penelitian Pendidikan, Pendekatan

Kuantitatif, Kualitatif, dan R\&D. Bandung: Alfabeta.

Suherman, E. (2003). Strategi Pembelajaran Matematika Kontemporer. Bandung: JICA Universitas Pendidikan Indonesia.

Surya, M. (2015). Psikologi Guru Konsep dan Aplikasi dari Guru untuk Guru. Bandung: Alfabeta.

Suyatno. (2009). Menjelajah Pembelajaran Inofatif. Sidoarjo: Masmedia Buana Pusaka.

Uno, H.B. (2007). Model Pembelajaran Menciptakan Proses Belajar Mengajar yang Kreatif dan Efektif. Jakarta: Bumi Aksara.

Uno, H. B.(2008). Model Pembelajaran. Jakarta: Bumi Aksara.

Wahyudin. (2008). Pembelajaran dan Model-Model Pembelajaran. Bandung: Dikat.

Wahyudin, (2012), Filsafat dan ModelModel Pembelajaran Matematika. Bandung: Mandiri.

Wirantiwi, A. (2011). Meningkatkan Kemampuan Komunikasi Matematik Siswa 74 SMA Melalui Pendekatan Pembelajaran Berbasis Proyek (Project Based Learning. (Skripsi). Universitas Pendidikan Indonesia: tidak dipublikasikan.

Zannati, G. N. (2017). Analisis Kemampuan Penalaran Matemtis Siswa pada Materi Bangun Datar di MTs Al-Musyahadah. In Prosiding Seminar Nasional Matematika dan Pendidikan Matematika STKIP Siliwangi 
(pp. 1585-1593). Bandung:

STKIP Siliwangi.

Zhanty, S.L. (2011). Peningkatan

Pemahaman Matematik Siswa

MTs dengan Menggunakan

Virtual Manipulative dalam

Contextual Teaching and
Learning (CTL). (Tesis).

Pascasarjana, Universitas

Pendidikan Indonesia: tidak dipublikasikan.

Trianto. (2007). Mendesain Model Pembelajan Inovatif Progresif. Kencana. 
